\title{
Intermédialités
}

Histoire et théorie des arts, des lettres et des techniques

Intermediality

History and Theory of the Arts, Literature and Technologies

\section{What is Necromedia?}

\section{Marcel O’Gorman}

Numéro 1, printemps 2003

Naître

URI : https://id.erudit.org/iderudit/1005450ar

DOI : https://doi.org/10.7202/1005450ar

Aller au sommaire du numéro

\section{Éditeur(s)}

Centre de recherche sur l'intermédialité

ISSN

1920-3136 (numérique)

Découvrir la revue

Citer cet article

O'Gorman, M. (2003). What is Necromedia? Intermédialités / Intermediality, (1), 155-164. https://doi.org/10.7202/1005450ar

\section{Résumé de l'article}

Cet article aborde la collusion entre mort et technologie en explorant l'adoption par l'industrie militaire des nouvelles technologies à des fins de destruction humaine; mais aussi les superstitions et les industries fantômes invoquées par l'afflux massif des nouvelles technologies, l'utilisation qui est faite de la technologie pour nous pousser vers une ère post-humaine qui prône et célèbre la fin d'un certain humanisme libéral, les promesses d'immortalité dont sont garantes les technologies et qui nous font oublier notre finitude. Cette exploration se trouve encadrée par diverses scènes médiatiques, extraites de deux récents films hollywoodiens, Vanilla Sky (Crowe, 2001) et American Beauty (Mendes, 1999). Cet article ne traite pas directement de ces films, il les emploie, plutôt, comme des études de cas, des récits induisant cette incorporation de la technologie dans la culture américaine. En définissant ce nouveau champ d'étude, et en créant ce nouveau concept, l'auteur espère susciter un intérêt pour une théorie nécromédiatique (Necromedia Theory), qui s'offre comme un antidote aux incorporations non critique des nouvelles technologies dans la vie quotidienne, et au développement incessant de la technologie pour elle-même.
Ce document est protégé par la loi sur le droit d'auteur. L'utilisation des services d’Érudit (y compris la reproduction) est assujettie à sa politique d'utilisation que vous pouvez consulter en ligne.

https://apropos.erudit.org/fr/usagers/politique-dutilisation/ 


\title{
What is Necromedia?
}

\author{
M A R C E L O' G O R M A N
}

«We can say "yes" to the unavoidable use of technological objects,

and we can at the same time say "no", insofar as we do not permit them to claim us exclusively and thus to warp, confuse, and finally lay waste to our essence.»

Martin Heidegger, Discourse on Thinking ${ }^{1}$

\section{TECHNOLOGY/MORTALITY: THE BIRTH OF NECROMEDIA}

n the spring of 2002 I accompanied my pregnant wife to an ultrasound test. I

had seen such tests before, and the technology has always fascinated me, but this test was different. As the technician moved the wand across my wife's abdomen, probing and prodding the tiny organism inside, a feeling of dread came over me. Still, I was fascinated enough with the technology that I wanted to discover the gender of the child. With a few well-directed swipes of the probe, the technician was able to spread the miniature legs and capture a freeze-frame. She then typed "male" in the upper left-hand side of the screen. I left the clinic in a state of shock, and was unable to focus on my work for the remainder of the day.

This act of inscription has been etched in my memory, aided perhaps by that fact that we have the entire scene-media scene par excellence-stored on videotape. What was it that caused this sense of dread? What left me feeling distracted, even deranged for the rest of that day? It was not until later that I sorted out the mêlée of emotions. To begin with, I found that the image on the monitor was very eerie, even ghostly. The silent, wispy, slow-moving image of this semihuman shape had the aura of a cryptic message from an alien world, or perhaps

1. Martin Heidegger, Discourse on Thinking, trans. John Anderson and E. Hans Freund, New York, Harper \& Row, 1966 [1959], p. 54. 
from the afterworld. In a word, I was stricken by the incomprehensibility of this scene, the seeming impossibility of it. This estranging sensation was short-circuited by the technician's intimate words: "You're going to have a son." And the ensuing emotions were then further complicated by her registering the fetus as "male" on the ultrasound screen. Perhaps it is this act of registration, identification and inscription that most affected me.

While this clinic scene seems, quite obviously, to be about birth, there is an entirely obverse dynamic that pervades it as well-a death dynamic. First, there is a prototypical element of mortality at play here. To hear the words, "You're going to have a son", forces one to come to terms with one's own mortality, in spite of any attempt to dismiss the stereotypical, patriarchal undertones of the situation. These words caused me to experience my own finitude ${ }^{2}$ in a most profound way. In a sense, they forced me to face my own dispensability, rendered me redundant. I was being replaced. But this media scene is not about me at all, and this profound sense of mortality passed relatively quickly. What has not passed is the impact of this media scene on the fetus, which is now a four month-old child. It was he who was rendered redundant in this scene; duplicated, outstripped, not by another human being, but by a recording technology. Such is the nature of necromedia.

This paper provides a synopsis of what I have come to call necromedia, the incorporation of death and technology. The anecdote above is a typical example of how the topic is approached in my research by means of media scenes. Typically these scenes, composed of brief human/machine interactions, are drawn from recent Hollywood films ${ }^{3}$. But the digression into personal anecdotes

2. Reference to the term "finitude" as the essence of being human is used throughout, and should indicate the influence of Martin Heidegger's philosophy on this text. In the words of Heidegger, "the self-assertion of technological objectification is the constant negation of death." (Martin Heidegger, "What are Poets For?", in Poetry, Language, Thought, trans. Albert Hofstadter, New York, Harper \& Row, 1971 [1952], p. 125.)

3. The strategy of using Hollywood cinema as a quasi-universal cultural referent is not easily justified. One could argue the point from several disciplinary methodologies. For example, I could insist, like Fredric Jameson, that Hollywood film is a repository of the American political unconscious just waiting to be brought to surface by a wise analyst (See Fredric Jameson, The Geopolitical Aesthetic, Bloomington, Indiana University Press, 1992). I would rather argue, however, that the theory I am proposing is quasi-universal, and Hollywood cinema merely provides a familiar pictorial vehicle for the delivery of the theory. What is at stake here is media theory, not film criticism. One could just as easily select media scenes from television programs, the daily newspaper, weblogs, or personal anecdotes collected on the subway. 
is an attempt to momentarily repress the spectacle of Hollywood that threatens to blind the reader from her own being. My hope is to draw on a variety of media scenes here in order to give the reader an impression of necromedia without providing an absolute, delimiting definition of the term. In any case, I hope to impress upon the reader the importance of accepting and even embracing one's finitude in a technological world built upon a false promise of immortality.

\section{TECHNOLOGY/ARTILLERY: AMERICAN BEAUTY}

The concept of the ultrasound, or echo-ranging sonar, was first patented in Great Britain by L.F. Richardson, one month after the sinking of the Titanic. The first working model was not invented until 1914, by Reginald A. Fessenden, a Canadian wireless pioneer who was once proclaimed "greater than Marconi". While Fessenden's invention seemed like a brilliant concept for averting icebergs, it proved more useful in assisting the United States Navy to seek and destroy German submarines. It seems logical, then, that in 1956 the first 36o-degree medical sonar images were achieved by immersing a patient in the degassed water contained in the disused turret of a B-29 bomber. Setting coincidences aside, this abridged history of ultrasound reveals the first and most straightforward component of necromedia theory: new technologies, if not invented by the military, will be adopted at their earliest stages for military purposes. For this reason alone, it is possible to establish a direct affinity between death and technology. The seemingly most unassuming technological invention can be repurposed for the sake of human destruction. But even without the intervention of the military, technologies have the capacity to betray and destroy us.

The film American Beauty (Mendes, 1999) offers a pertinent perspective on the ability of digital media to invade the private, domestic space of a family household and wreak havoc on those who dwell there. Unlike techno-science thrillers and science-fiction movies that draw a very distinct line between technology and mortality, American Beauty does so in a much more subtle, naïve way. Consider, for example, the scene in which Lester, played by Kevin Spacey, yields to his imprudent crush on his daughter's teenage girlfriend, and dials her tele-

4. For a concise yet comprehensive history of ultra-sonography, see Dr. Joseph Woo, "A Short History of the Development of Ultrasound in Obstrectics and Gynecology", http://www.ob-ultrasound.net/history.html, last revised, October, 2002, accessed February 12, 2003. 
phone number. His attempt is thwarted, but the young girl, making handy use of the telephone code *69, "busts" Lester by tracing his call. This digital enhancement to telephony initiates the dissolution of the Burnham family's domestic space. This space is further disintegrated in the film by correlated technologies: the Smiley Burger wireless radio system, over which Lester hears his adulterous wife and her lover, and Rickey's pager, which beeps at the Fitts dinner table, spurs the Colonel's suspicion, and leads him to the videotapes of Lester in Rickey's room. In the words of Marshall McLuhan:

The older, traditional ideas of private, isolated thoughts and actions $[. .$.$] are very$ seriously threatened by new methods of instantaneous electronic information retrieval, by the electrically computerized dossier bank - that one big gossip column that is unforgiving, unforgetful and from which there is no redemption, no erasure of early "mistakes".

The most insidious technology of betrayal in this film, the video camera, plays a much more prominent role, and is linked more obviously to the destruction of domestic space and of the main character, Lester Burnham.

While wireless communications devices are most obviously linked to the armed forces, the camera's military history is less familiar. In his landmark work, War and Cinema, Paul Virilio investigates the ways in which film played a key role in the World Wars ${ }^{6}$. From propaganda movies to surveillance cameras mounted on fighter planes, the wars were won partly by means of celluloid. What is most interesting about this study is the manner in which Virilio categorically associates guns and video cameras. Beginning with the chronophotographic gun (1882), Etienne Jules Marey's precursor to the video camera, Virilio demonstrates that the sight of a gun and the sight of a camera have always been close cousins in a "cohérence fatale qui s'établit toujours entre la fonction de l'œil et celle de l'arme"." This notion may seem outlandish at first glance (surely cameras, like ultrasound machines, share only a coincidental history with guns !), but a closer look at the essence of recording technologies clarifies their complicity with death.

To return to American Beauty, what makes the video camera more insidious than the other communication devices in the film is that it is first and foremost a

5. Marshall McLuhan, The Medium is the Massage, Corte Madera, CA, Ginkgo Press, 2000 [1967], p. 12.

6. Paul Virilio, Guerre et cinéma I. Logistique de la perception, Paris, Éditions Cahiers du cinéma, coll. "Essais", 1991 [1984].

7. Paul Virilio, Guerre et cinéma, p. 122. 
recording device. As Friedrich Kittler has attempted to demonstrate in Gramophone, Film, Typewriter, "since 1880, there has been a storage medium for each kind of betrayal ${ }^{8}$." While Kevin Spacey's character is "busted" by a variety of technologies in the film, his ultimate demise is linked most directly to the video footage that his neighbor, Rickey Fitts, has surreptitiously recorded of him. Rickey's father, Colonel Fitts, views the footage of naked Lester lifting weights, and ultimately pieces together (erroneously) the notion that Rickey and Lester are engaged in a homosexual relationship. Lester immediately becomes the Colonel's target; first as the target of his repressed homosexual desires, and second as the target of his handgun. Rickey shoots Lester with a video camera; the Colonel shoots Lester with a pistol. Who is more responsible for Lester's death? In the words of Friedrich Kittler, "the transport of pictures only repeats the transport of bullets".

Once again, it may seem irrational to argue that a camera is just as deadly as a gun, but consider the evidence. The television myth of the weathered American Indian (the one who refuses to have his photo taken for fear of losing his soul) is instructive here. While the recording of an individual's image may not provoke immediate physiological death, it can trigger a more subtle demise: death by repetition $^{10}$. The recording of Lester renders him infinitely repeatable, redundant. His own physical life takes the backseat to what is registered on Rickey's mini-Dv tape, which takes on a life of its own. The result, in this case, is tragic.

8. Friedrich Kittler, Gramophone, Film, Typewriter, Stanford, Stanford University Press, 1999, p. 85 .

9. Friedrich Kittler, Gramophone, Film, Typewriter, p. 124.

10. The alliance of death and photography is a central concern of Roland Barthes in La chambre claire. Barthes sees death as the ultimate implication of a photograph: "Au fond, ce que je vise dans la photo qu'on prend de moi [...] c'est la Mort: la Mort est l'eidos de cette Photo-là" (Roland Barthes, La chambre claire. Note sur la photographie, Paris, Éditions de l'Étoile, Gallimard, Le Seuil, 1980, p. 32). Barthes also notes that the photograph possesses a resurrectional quality, which he observes from an essentially nostalgic point of view. Arguably, my thesis could be deemed nostalgic as well, not in the specific way that Barthes was nostalgic for his deceased mother, but generally nostalgic about the loss of the fleshly element of "being". The difference between my thesis and that of Barthes is more a question of degree than of kind. With the current proliferation of photographic devices, electronic databases, surveillance systems and the general mass media glut that renders suspect any notion of "presence" or "reality", we are constantly confronted by the inevitability of our own death. In addition to this, one must consider that there is a difference in the degree of presence between photography (as discussed by Barthes) and video or even 3dimensional moving images. 
The collusion of death and film is brought home most profoundly in American Beauty by the fact that the entire movie is narrated by a dead man. This impossibility made possible by film reveals a byproduct of technology's capacity to "steal our soul"; in doing so, it also yields the promise of immortality. It should come as no surprise that many of the first feature films involved Doppelgangers, spirits and vampires; film makes us the promise of an other, eternal existence. But we should heed the foreboding aura of malevolence that pervades these early films. It is all too tempting - and dangerous - to believe that technologies will indeed lead us to everlasting life.

\section{TECHNOLOGY/IMMORTALITY: VANILLA SKY}

The notion of being "immortalized on the big screen" is a double-edged sword. In the theatre, avid movie fans find solace in projecting themselves into the fictional lives of their favorite Hollywood stars. Outside of the theatre, they are fascinated by the supposed "real" lives of the stars fabricated for the pages of supermarket tabloids. What, indeed, is the "real" life of a movie star? These individuals play out the greater part of their existence on recordable media (celluloid, vHs, DVD), and the rest is spent dodging the live illegitimate recordings by paparazzi seeking to compromise the image that has become more important than their actual, physical being. What's more, once an actor's ageing flesh ceases to reflect the idealized, recorded image that has been projected and reprojected myriad times for an attentive audience, that flesh (the actor's physical being) becomes completely redundant, and is forced to take the backseat to the media images that have defined him. The result is either an actor in exile, or the employment of "body doubles" who more closely represent how the actor is "supposed" to appear. Hollywood stars are indeed immortalized, but at the cost of their own being.

The sadness of this death by repetition may be observed most palpably in the film Vanilla Sky (Crowe, 2001). Consider for a moment the scene in which Penelope Cruz's character, Sofia Serrano, interacts with the 3-dimensional hologram of the jazz impresario, John Coltrane. As Sofia, the supposed embodiment of youthful innocence, gingerly approaches the ghostly stereogram, an effect worthy of the Brothers Grimm is produced. Beauty chides death as Sofia playfully waves her hand through the hologram, scattering the beaming lasers that make the illusion possible. But then, this is not a possible illusion. Although the computing power required to generate a hologram of this size is available, it has not yet been put to such aesthetic purposes. There are other, more practical uses for holograms. For example, holographic interferometry is used to design containers 
that store or transport nuclear materials, and transmission holograms provide sophisticated heads-up displays for U.S. fighter pilots. While the spectral hologram of Coltrane presents us with a disturbing vision of the living dead, the hologram technology used to create this specter is equally deadly, linked as it is, like all media, to warfare.

The hologram, in this case, is what I would call a displacement technology. While a full-scale hologram of Coltrane is the stuff of science-fiction, the essence of that hologram, and what it reveals about the relationship between human life and technology, is very real, and is exhibited in other, more realistic technologies. In this case, I would argue that the hologram is a displacement of film technology. If the spectral image of Coltrane gives us a frisson, then the video image of Tom Cruise should strike us as equally chilling. This movie, disparaged by critics on all shores, comes off as a self-promotional, semi-autobiographical exploration of Cruise dealing with his own mortality, his own split existence as a graying, middle-aged man, and an eternally youthful media image. The overwrought, reality-challenged plot that provoked the ire of many a film critic should be seen in parallel with the reality-challenged life of the movie's main cast member. The "Lucid Dream", a dreamlike state that Cruise's character, David Aames, lives out while in cryogenic suspension, is not a far cry from the schizophrenic screen life that dominates the existence of a Hollywood movie star such as Tom Cruise.

Vanilla Sky explores some of the ramifications of living in a posthuman ${ }^{11}$ world. The "Lucid Dream", for example, is a hyper-mediated life constructed by programmed memories that are implanted in the human brain while the body remains immobile. In this sense, the "Lucid Dream" is a displacement of other technologies of disembodiment: the Internet, virtual reality, remote control. But we need not look so far into the evolution of technology to uncover where the "Lucid Dream" might be displaced. The "Lucid Dream" seems to be an obvious metaphor for cyberspace in its Internet incarnation, but it also reveals the way film technology constructs the reality of its stars. Beyond the reality of star-system, Vanilla Sky should be seen as a film about the way in which media images construct reality, tout court.

11. For an excellent genealogy of the posthuman turn, see Katherine Hayles, How we Became Posthuman: Virtual Bodies in Cybernetics, Literature, and Informatics, Chicago, University of Chicago Press, 1999. See also Francis Fukayama, Our Posthuman Future, New York, Farrar, Straus and Giroux, 2002. Fukayama looks at biotechnology and the fate of political order in a posthuman world. 
The DVD version of Vanilla Sky is indispensable to a reading of the film from the perspective of necromedia theory. First of all, the DVD offers footage of the Vanilla Sky press tour, which includes a superb clip of Tom Cruise displaying utter befuddlement at the following question delivered by a clever French reporter: "Are you actually afraid of the deletion of memories? In other words, are you still real?" This odd question (why was it included on the DVD?) points to the way in which Tom's own posthuman existence is composed of the "false memories" of those who have seen his movies. Should these memories be deleted, what would remain of him?

The theme of memory seems to pervade Vanilla Sky from Coltrane's eerie wailing of "My Favorite Things" to the elevator scene in which David Aames's "real memories" are returned to him. In the director's voiceover-a second good reason to view the DVD version of the film - Cameron Crowe goes to great lengths in explaining this elevator scene. The scene portrays David Aames with his cryogenic/cognitive technician, climbing to the top of a New York city skyscraper while David's “real life” memories flash before him. Interspersed in these memories are clips from movies and images from album covers. The technical-support man suggests to David that these images made it possible to create the idealistic, alternate reality of the "Lucid Dream". As Cameron Crowe reveals in the voiceover, however, this is not all science-fiction:

All of these things are sort of the pop cultural signposts that we all have in our lives: our favorite movie, To Kill a Mockingbird [Mulligan, 1962]; an album cover, as we talked about earlier, that expressed what love was; a vision of fatherhood that came from Gregory Peck. I think all that stuff is lodged in all of our minds. Jules et Jim [Truffaut, 1962], a great laugh you try and find in life, and when you see it something touches you and you don't always know why. But sometimes it's because it's linking up with images that became you as you grew up. And that was one of the big reasons to make the movie, I thought. Let's celebrate the things that create us ${ }^{12}$.

It seems, then, that the effects of media do not only make an impact on our lives tangentially, but that our very lives are "created" by media images. It is not surprising, perhaps, to hear this from a movie director. After all, the persistence of the media image, infinitely more effective than botox, is the cryogenic elixir of Hollywood. Audrey Hepburn, Sean Connery, Tom Cruise may die, but they are immortalized in the memories of movie-goers, some of whom will confuse their own memories with scenes in a moving picture.

12. Cameron Crowe, Vanilla Sky (director's voiceover), DVD, 2001. 


\section{TECHNOLOGY/PEDAGOGY/INTERDISCIPLINARITY: ELECTRONIC CRITIQUE AND NECROMEDIA}

In How we Became Posthuman, Katherine Hayles suggests that

the posthuman, although still a nascent concept, is already so complex that it involves a range of cultural and technical sites, including nanotechnology, microbiology, virtual reality, artificial life, neurophysiology, artificial intelligence, and cognitive science, among others ${ }^{13}$.

However, those who fear the effects of the posthuman should realize that the real danger is not some science fictional cryogenic technology or a futuristic version of vR. These fantasies distract us from the posthuman technologies that are in our line of sight on a daily basis, not only at the cinema, but in our living rooms and offices, alongside the freeway, in the subway, etc. Still, Hayles is one of the few postmodern theorists who not only identifies the symptoms of our posthumanity, but also one who suggests that we need to intervene in the media culture of posthumanity by imagining ourselves differently:

If my nightmare is a culture inhabited by posthumans who regard their bodies as fashion accessories rather than the ground of being, my dream is a version of the posthuman that embraces the possibilities of information technologies without being seduced by fantasies of unlimited power and disembodied immortality, that recognizes and celebrates finitude as a condition of human being, and that understands human life is embedded in a material world of great complexity, one on which we depend for our continued survival ${ }^{14}$.

Although Hayles does not specifically mention Martin Heidegger here, she is explicitly echoing his greatest concern about modern humanity: our resistance to accepting the finitude which is the essence of being human.

Yet how exactly does one go about embracing or celebrating finitude? I recently suggested to a colleague that we could try buying advertising time at the cineplex and run "death trailers 'before the feature film' : ENJOY THE SHOW, BUT REMEMBER YOUR FINITUDE". As flippant as this idea may seem, I present it with the greatest sincerity. In order to intervene in the technological effects that threaten to "lay waste to our essence", I would argue that we must make use of the very tools that engender the threat. What does this mean? From the perspective of

13. Katherine Hayles, How we Became Posthuman, p. 247.

14. Katherine Hayles, How we Became Posthuman, p. 5. 
scholars, critics and pedagogues, if we are to pursue a version of the posthuman that embraces finitude, and that accepts the body's embeddedness in a real and fragile world, then theory itself is not enough. The answer may lie in a more concerted effort to combine theory and practice, pedagogy being the primary venue for this combination ${ }^{15}$. For myself, it means that students in the multidisciplinary Electronic Critique (E-Crit) Program in which I teach must not only learn about the critical work of Foucault and Derrida, but must also learn algorithms and scripting languages. Most importantly, they will learn how to "handle" the inner-workings of a microprocessor, engaging with the computer on a much less abstract level.

In reference to the interdisciplinary nature of cybernetics, Katherine Hayles has shown that "when the body is revealed as a construct, subject to radical change and redefinition, bodies of knowledge are similarly apt to be seen as constructs, no more inevitable than the organic form that envisions them ${ }^{16}$." The inclusion of thanatology — death studies — in Media Studies, on even the subtlest level, may be one way to bring the interdisciplinary morphing of this subject back to the ground of the body. As a purveyor of interdisciplinary Necromedia Theory, balancing theory and practice also means teaching more than the uncanny relationship between death and media, but also addressing the reality of death itself. Students enrolled in the Electronic Critique Program are not only subjected to poststructural theory and Hollywood film, but they also encounter texts such as Elizabeth Kubler-Ross's On Death and Dying ${ }^{17}$, and attend lectures on the topic of death by palliative care specialists and terminally ill patients.

This pedagogical approach is not intended to promote a cult of morbid luddites who make ironic use of technology, but to foster the growth of individuals who are attuned to their own finitude, and who strive incessantly to understand the complex relationship between their bodies, their minds, and the apparatuses that threaten to separate the two.

15. For additional clarification of this concept, see Marcel O'Gorman, "You Can't Always Get What You Want: Transparency and Deception on the Hardware Fashion Scene", Ctheory, December 6, 2000, http://www.ctheory.net/text_file.asp?pick=227, accessed January 22, 2002.

16. Katherine Hayles, How we Became Posthuman, p. 85.

17. Elisabeth Kubler-Ross, On Death and Dying, New York, Macmillan, 1991. 